\title{
Clinical aspects of dento-maxillary abnormalities to the members of the same family
}

\author{
Aspecte clinice ale anomaliilor dento-maxilare la membrii aceleiași familii \\ Mioara Decusară ${ }^{1}$, Anamaria Zaharescu' ${ }^{1}$, Ada Ștefănescu', Delia Daragiu², \\ Dorina-Cerasella Șincar ${ }^{1}$ \\ ${ }^{1}$ Departamentul de Medicină Dentară, Facultatea de Medicină și Farmacie, \\ Universitatea „Dunărea de Jos“, Galați, România \\ ${ }^{2}$ Disciplina Ortodonţie, Facultatea de Medicină Dentară, \\ Universitatea „Titu Maiorescu“, Bucureşti, România
}

\begin{abstract}
Dento-maxillary abnormalities are considered to be the consequence of the problems of quantitative development of position, direction and rhythm of the three elements of the dento-maxillary apparatus (teeth, alveolis and maxillary bones), associated with occlusal and neuro-muscular functional disorders. Heredity plays an important role in triggering this process, but also, the local, general and environmental factors, which intervene prenatally and postnatally, so that, to rhe members of the same family, the clinic and the evolution of dento-maxillary anomalies may present different aspects.

The purpose of this article is to present some clinical aspects of dento-maxillary anomalies in members of the same family (parents, siblings). The cases were selected from a group of 386 patients treated for a period of 40 months in a private orthodontic practice in Brăila.

The research of the etiology of a dento-maxillary anomaly as a hereditary determinism allows the application of a treatment adapted to the clinical case.
\end{abstract}

Keywords: hereditary analysis, dento-maxillary anomalies

\section{REZUMAT}

Se consideră că anomaliile dento-maxilare sunt consecința unor probleme de dezvoltare cantitativă de pozitie, de direcție și de ritm a celor trei elemente ale aparatului dento-maxilar (dinți, alveole și oase maxilare), asociate cu tulburări funcționale ocluzale și neuro-musculare. În declanșarea acestui proces un rol important îl au transmiterea ereditară, dar și factorii locali, generali și de mediu, care intervin atât prenatal, cât și postnatal, astfel încât, la membrii aceleiași familii, clinica și evoluția anomaliilor dento-maxilare, pot prezenta aspecte diferite.

Scopul acestui articol este de a prezenta câteva aspecte clinice ale anomaliilor dento-maxilare prezente la membri din aceeași familie (părinți, frați, surori). Cazurile au fost selectate dintr-un lot de 386 de pacienți tratați pe o perioadă de 40 luni într-un cabinet privat de ortodonție din Brăila.

Cercetarea etiologiei unei anomalii dento-maxilare ca determinism ereditar permite aplicarea unui tratament adaptat cazului clinic.

Cuvinte cheie: analiză ereditară, anomalii dento-maxilare

\section{INTRODUCERE}

Mulți practicieni ortodonți se gândesc la ereditate în ceea ce privește controlul și prezicerea creșterii faciale, pentru a stabili limitele la ceea ce poate fi schimbat cu ajutorul tratamentului ortodontic Astfel, dacă ,genetica“ poate provoca un fenotip care este programat genetic, atunci medicii ortodonți pot fi limitați în ceea ce pot face pentru a-l schimba. Ca exemplu, o malocluzie sau o altă modificare anatomică pot prezenta un model complex de moştenire sau etiologie, aşa cum fac majoritatea fenotipurilor (1). Cercetarea etiologiei unei anomalii dento-maxilare are o importanță deosebită în diagnosticarea ei, deoarece cunoașterea patogeniei 
permite aplicarea unui tratament adaptat cazului clinic (2).

Etiopatogenia prenatală include totalitatea factorilor nocivi care intervin la un moment din viaţa intrauterină și pot acționa asupra embrionului sau a fătului, fiind numiți agenți teratogeni (3). Când intensitatea este mai mică, pot determina doar oprirea sau tulburarea dezvoltării unui organ sau a unei funcții, determinând o malformație congenitală. Factorii teratogeni cei mai incriminaţi sunt $(4,5)$ :

- Tulburări utero-placentare și hormonale materne

- Infecții virale (rubeolă, rujeolă, varicelă, gripă, hepatită epidemică)

- Infecții bacteriene (sifilis, listerioză)

- Infecții parazitare (toxoplasmoză)

- Factori endocrini (diabet zaharat)

- Factori imuni (boli autoimune)

- Factori mecanici (boală amniotică)

- Factori chimici

- Factori fizici (radiațiile X)

Factorii filogenetici pot fi consideraţi factori patogeni în cadrul anomaliilor dento-maxilare în sensul întârzierilor în evoluția filogenetică a unor elemente ale acestui aparat, iar altele anticipează volumul, forma, structura şi funcțiile sistemului dentar ale omului din viitor $(5,6)$.

Modificările filogenetice ale sistemului dentar $(3,7,8,9)$

1. Anomalii dentare de număr - se constată o reducere numerică a ultimului dinte din grupul dentar diferențiat: IL superior, IC inferior, PM2, M3

2. Anomalii dentare de formă - se constată reducerea formei incisivilor laterali superiori și a ecuatorului molarilor permanenți și situarea punctelor de contact în $1 / 3$ ocluzală

3. Modificări în poziția și înclinarea dinţilor, asociate sau nu cu modificări ale maxilarelor

4. Modificări la nivelul arcadelor alveolare - reducerea dimensiunii sagitale a proceselor alveolare, asociată cu lărgirea acestora, fixarea mai posterioară a proceselor alveolare pe baza lor maxilară, apariția mentonului proeminent, producerea incongruențelor dento-alveolare.

Determinismul genetic influenţează dezvoltarea facială verticală, precum și anumiți parametri de dezvoltare mandibulară $(2,10)$.

Anumite elemente ale aparatului dento-maxilar sunt determinate genetic: forma maxilarelor, a dinților și mărimea lor, precum și vârsta și cronologia erupției dentare $(3,10,11,12)$. Anumite anomalii dento-maxilare sunt cunoscute ca având transmitere erditară: prognatismul mandibular anatomic, ocluzia adâncă acoperită, anomalii dentare de număr, ocluzie deschisă, compresiunea de maxilar, diastema vera și dizarmoniile dento-alveolare $(3,13,14,15)$.

În sistemul dentar, tulburările de structură cu caracter ereditar sunt: maladia Cap de Pont, amelogeneza imperfectă ereditară și dentinogeneza imperfectă ereditară, iar susceptibilitatea (predispoziția) la carie, distrofiile dentare de formă, poziție și dimensiune sunt influențate ereditar $(3,9)$.

În ceea ce privește părțile moi, macroglosia, inserțiile de fren și muscular (maseter), anchiloglosia, microstomiile, de cele mai multe ori în asociere cu unele anomalii dento-maxilare sau sindroame genetice, pot apărea ca urmare a unei influențe de transmitere ereditară $(16,17)$.

În sistemul parodontal, parodontita marginală cronică şi parodontita cronică juvenilă de tip distrofic pot avea o predispoziție la transmitere ereditară $(18,19)$.

\section{SCOP}

Scopul acestui articol este de a prezenta câteva aspecte clinice ale anomaliilor dento-maxilare prezente la membri din aceeași familie (părinți, frați, surori), aspecte care pot fi asemănătoare sau nu.

\section{MATERIAL ŞI METODĂ}

Fără să aibă pretenția unui studiu statistic, au fost selectate câteva cazuri clinice ale unor membri din aceeași familie, tratate ortodontic pentru anomalii dento-alveolare cu sau fără transmitere ereditară dovedită.

Cazurile au fost selectate dintr-un lot de 386 de pacienți tratați pe o perioadă de 40 luni într-un cabinet privat de ortodonție din Brăila, pacienții și aparținătorii (pentru minori) exprimându-și consimțământul de participare la învăţământul medical.

\section{CAZURI CLINICE}

1. Surori gemene identice, cu anomalie dentoalveolară clasa II, subdiviziunea 1 , cu rapoarte 
distalizate unilateral dreapta, înghesuire și prodenție superioară, asimetrică sagital și transversal (fig. 1 și fig. 2).

2. Surori gemene identice cu anomalie dento-alveolară clasa I Angle, cu treme și diastemă, datorate microdenţiei și frenului labial superior cu inserție joasă (fig. 3 și fig. 4).
3. Mamă și fiică, cu anomalie dento-alveolară clasa a III-a Angle, blocarea mișcărilor de propulsie mandibulară și conducere canină, cu abrazii ale muchiilor incizale datorate înghesuirii dentare şi ocluziei traumatizante (fig. 5 și fig. 6).

4. Două surori cu anomalie dento-alveolară de număr: cea mare cu anodonție de premolari maxi-
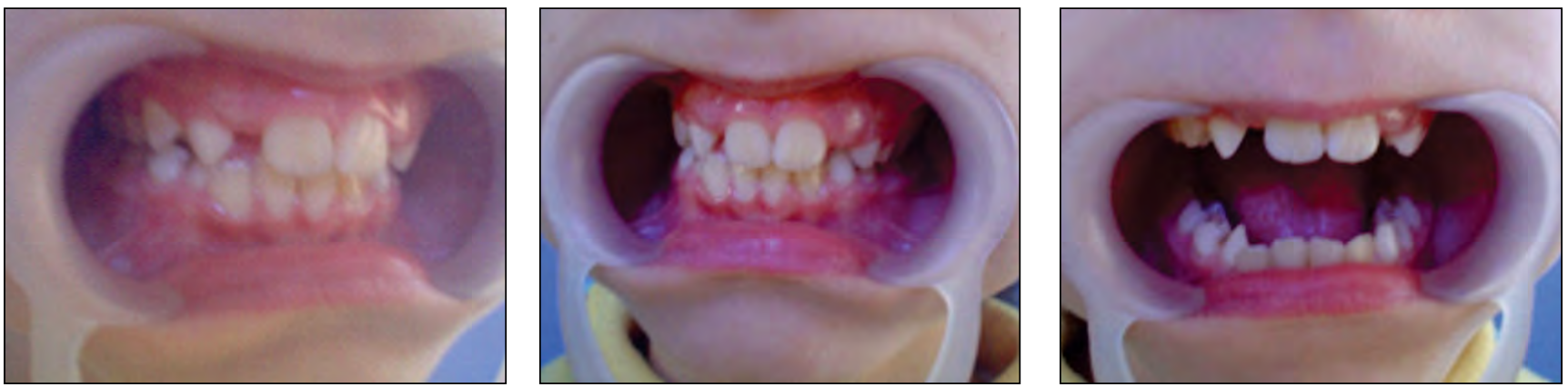

FIGURILE 1A,B,C. S.A. - Aspectul arcadelor dentare din normă frontală şi laterală la 8 ani
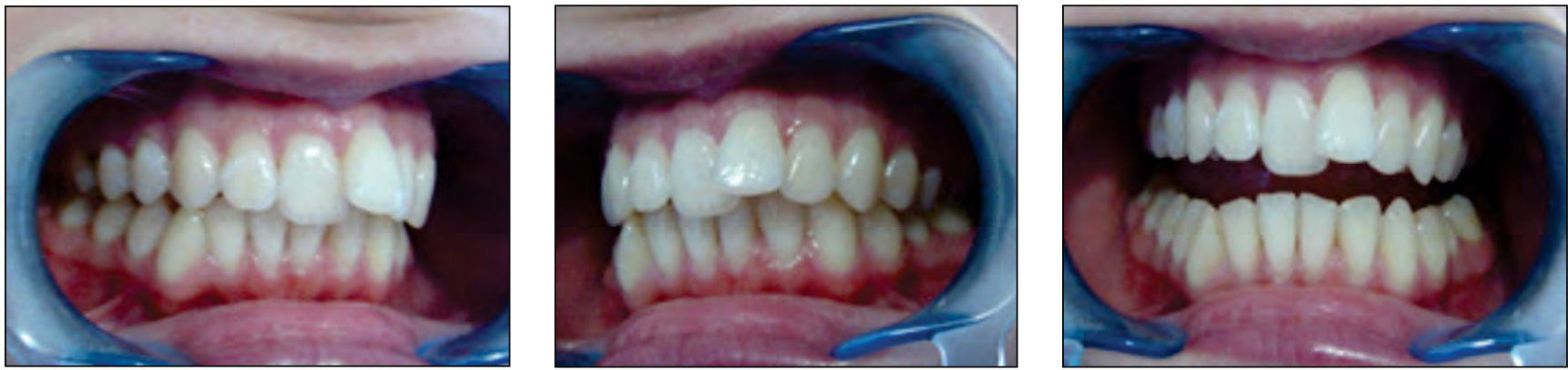

FIGURILE 1D,E,F. S.A. - Aspectul arcadelor dentare din normă frontală şi laterală la 17 ani
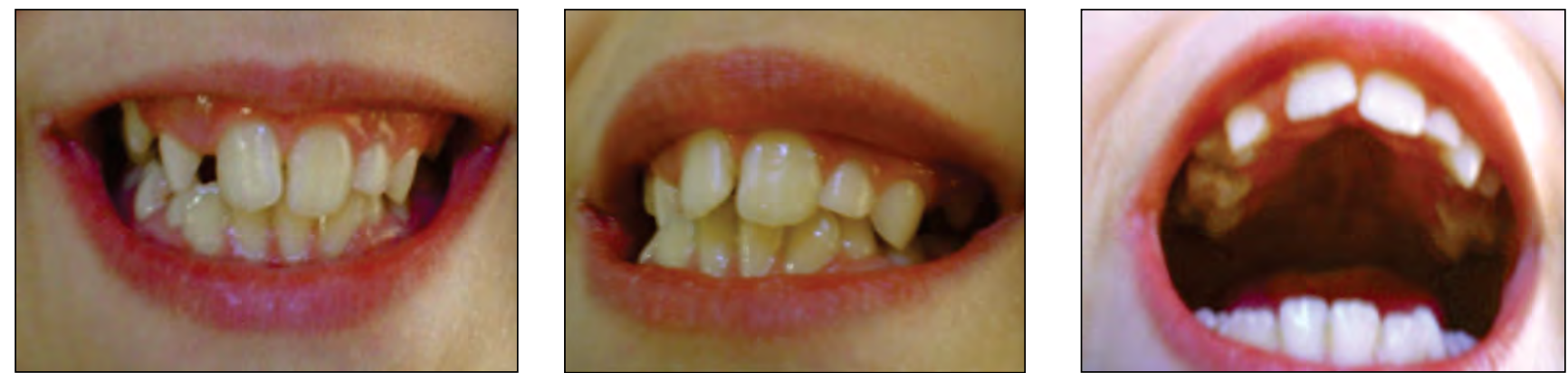

FIGURILE 2A,B,C. S.I. - Aspectul arcadelor dentare ale surorii gemene din normă frontală şi laterală la 8 ani
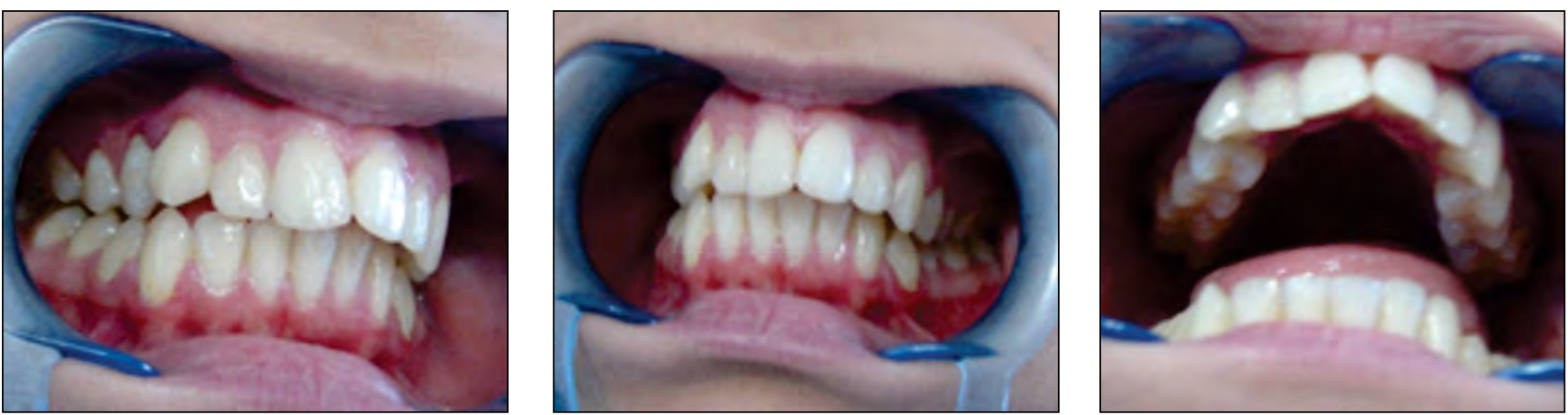

FIGURILE 2D,E,F. S.I. - Aspectul arcadelor dentare ale surorii gemene din normă frontală şi laterală la 17 ani 

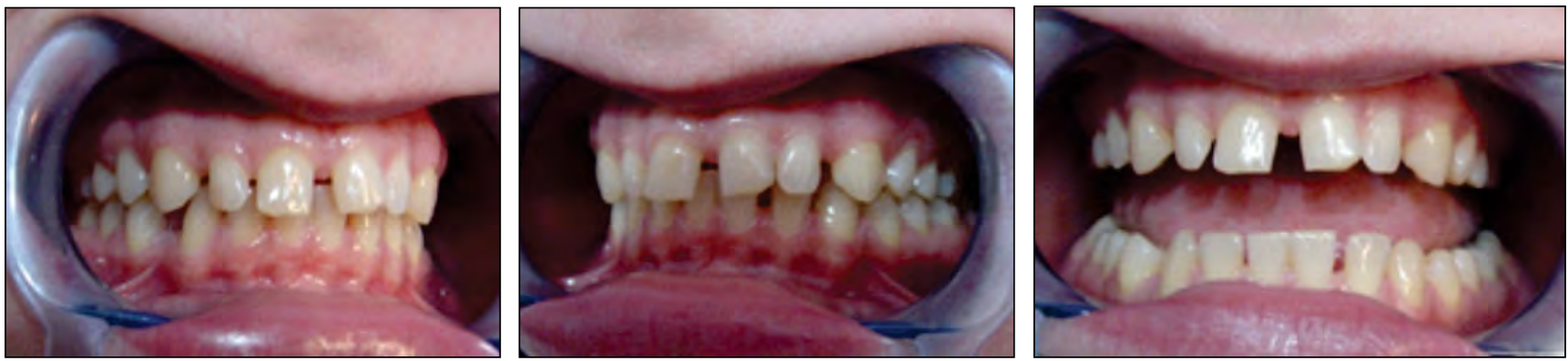

FIGURILE 3A,B,C. S.I., 21 ani - Aspectul arcadelor dentare în normă frontală şi laterală dreaptă şi stângă
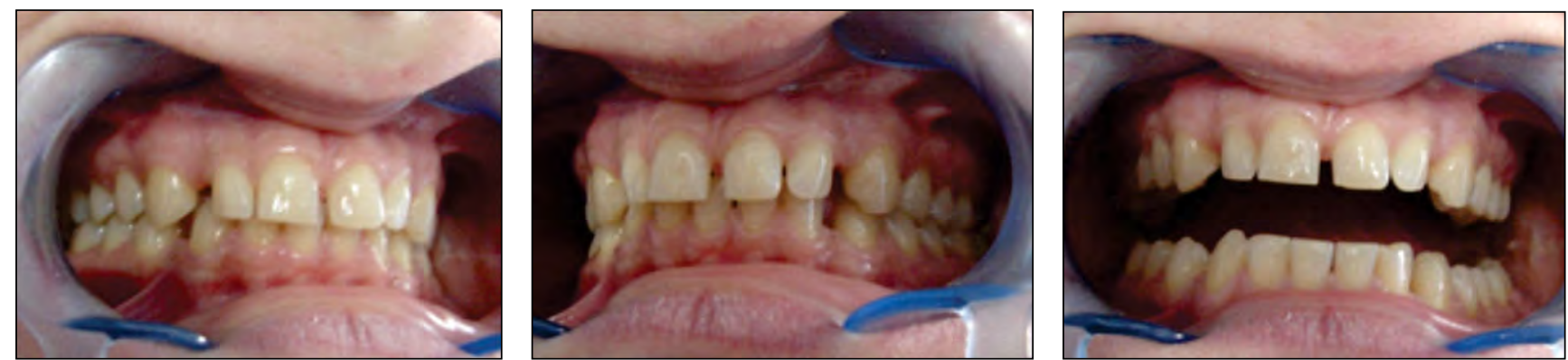

FIGURILE 4A,B,C. S.F., 21 ani - Aspectul arcadelor dentare ale surorii gemene în normă frontală şi laterală dreaptă şi stângă
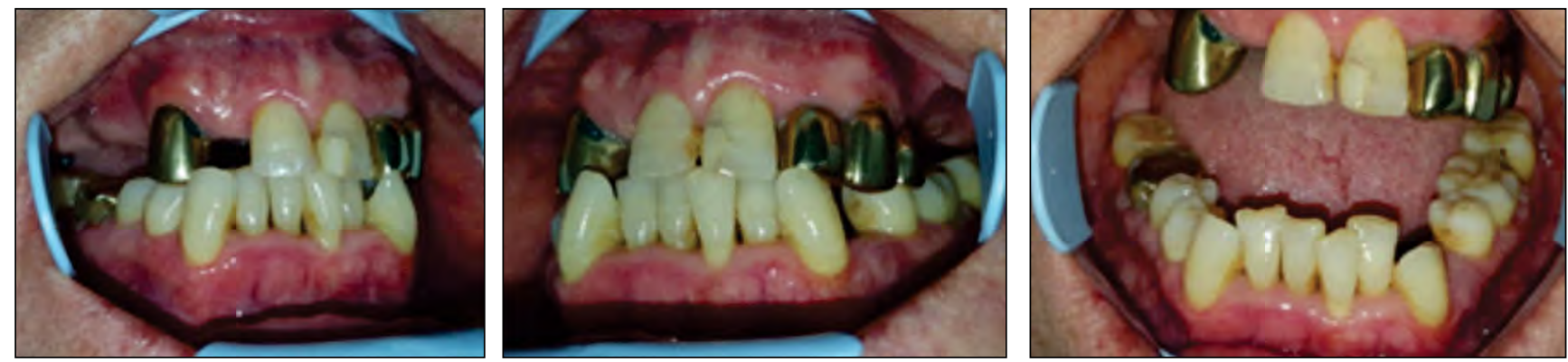

FIGURILE 5A,B,C. D.V., 64 ani, mama - Aspectul arcadelor dentare în ocluzie statică în normă laterală dreaptă şi stângă şi frontală
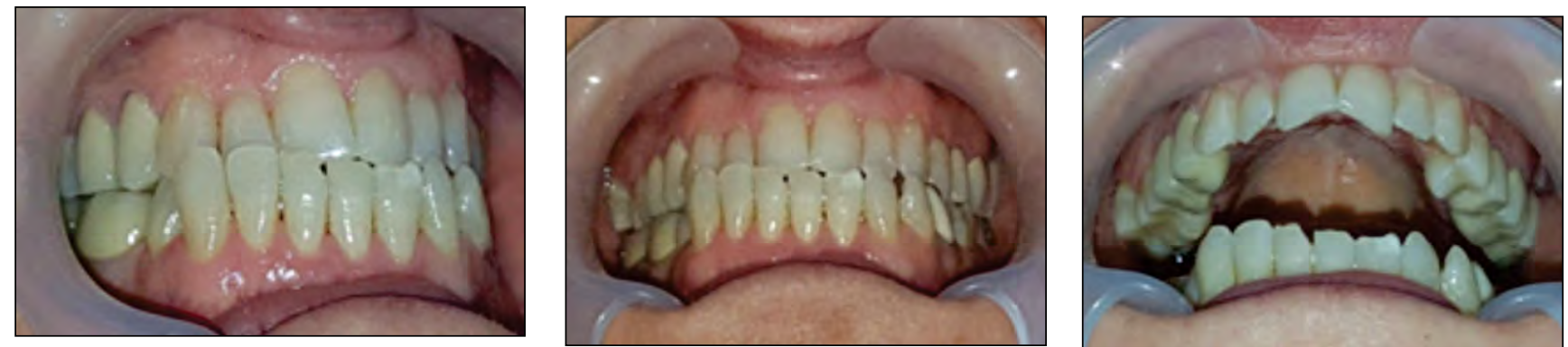

FIGURILE 6A,B,C. I.V., 42 ani, fiica - Aspectul arcadelor dentare în ocluzie statică în normă laterală dreaptă şi stângă şi frontală

lari, iar cealaltă, cu anodonție de premolari secunzi mandibulari (fig. 7 și fig. 8).

5. Frați cu anomalii dento-maxilare diferite: fratele mai mare, cu anomalie dento-alveolară clasa I Angle, cu înghesuire dentară și aspect atipic al incisivilor maxilari, iar sora mai mică, cu anomalie clasa I Angle, cu spațieri dentare maxilare ca urmare incisivilor laterali nanici (fig. 9 și fig. 10).
6. Două surori cu anomalie dento-alveolară clasa a II-a Angle, determinată de retrognatism mandibular şi un tipar de rotaţie anterioară mandibulară, cu transmitere ereditară de la mamă: cea mică prezintă subdiviziunea 2, cu supraacoperire frontală de 1/1 (ocluzie adâncă acoperită), iar cea mare prezintă subdiviziunea 1 , cu prodenție maxilară și inoclu- 

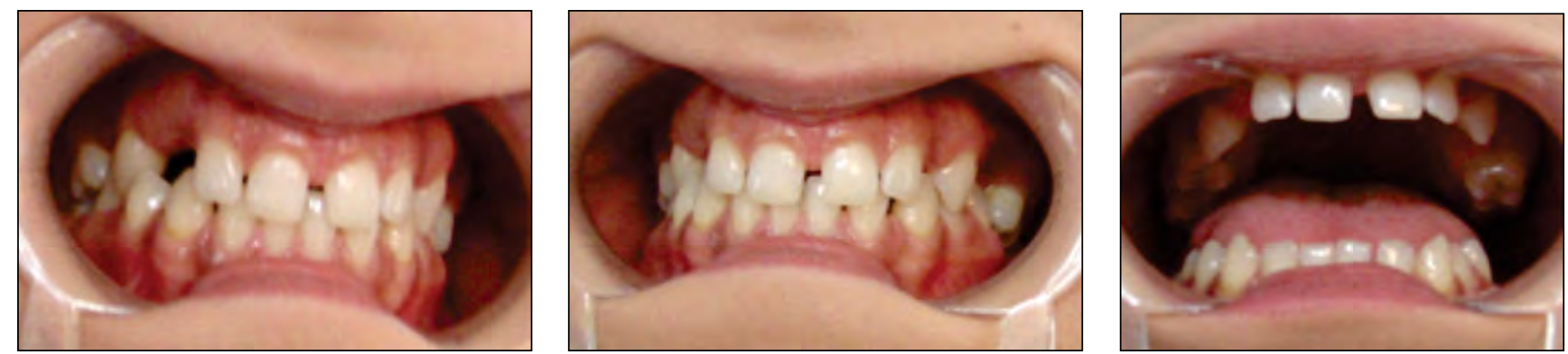

FIGURILE 7A,B,C. P.S., 24 ani - Aspectul arcadelor dentare (anodonţie de premolari maxilari) în ocluzie statică în normă laterală dreaptă şi stângă şi frontală
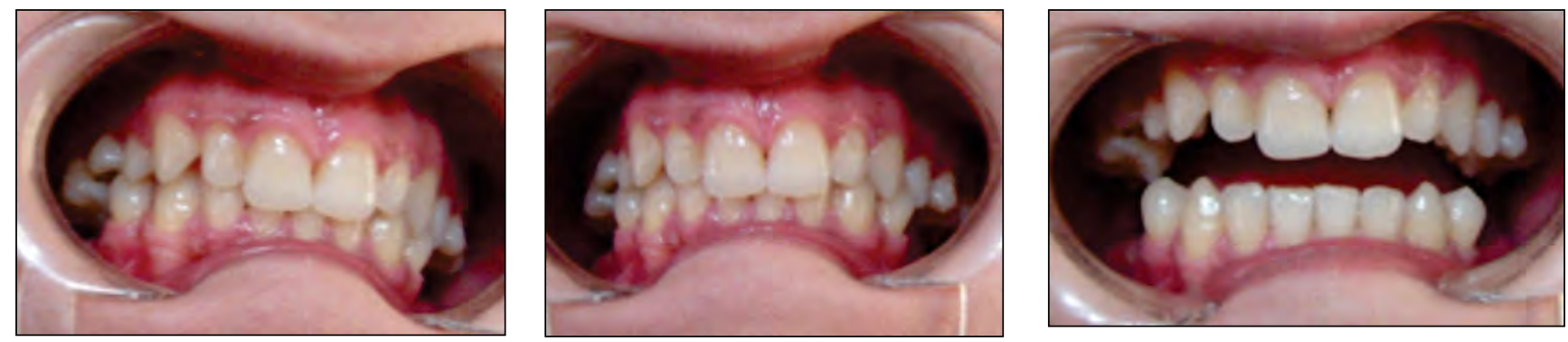

FIGURILE 8A,B,C. P.N., 22 ani - Aspectul arcadelor dentare (anodonţie de PM2 mandibulari) în ocluzie statică în normă laterală dreaptă şi stângă şi frontală
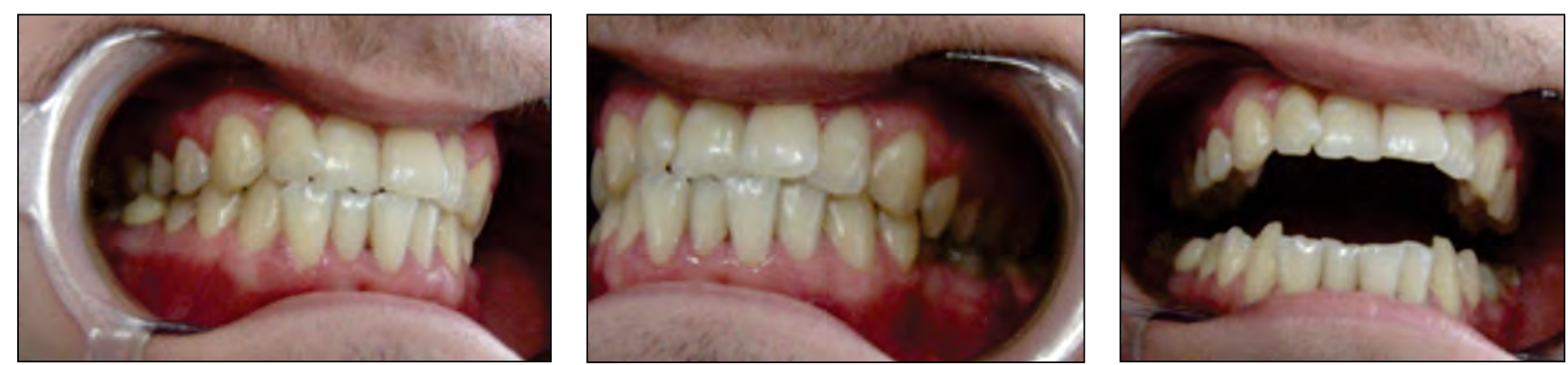

FIGURILE 9A,B,C. Z.F., 21 ani, sex masculin - Aspectul arcadelor dentare (înghesuire dentară) de normă laterală dreaptă şi stângă în ocluzie statică şi normă frontală
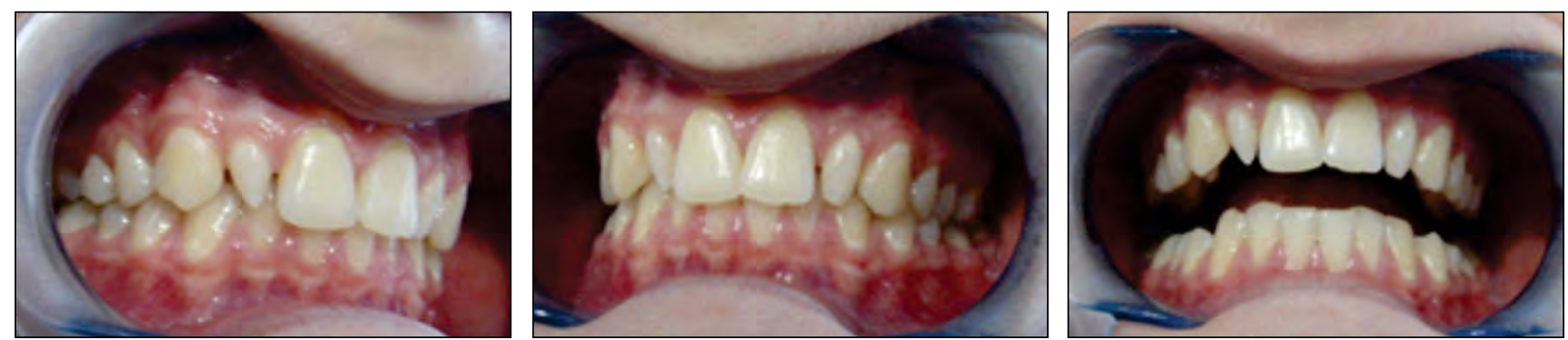

FIGURILE 10A,B,C. Z.M., 16 ani, sex feminin - Aspectul arcadelor dentare (treme maxilare) de normă laterală dreaptă şi stângă în ocluzie statică şi normă frontală

zie sagitală de 5 mm (ocluzie adâncă în acoperiș) (fig. 11 și fig. 12).

7. Trei surori, cu anomalii dentare izolate: cea mare prezintă nanism al incisivilor laterali maxilari şi angrenaj invers între 12 și 42 (anomalie de formă și dimensiune) (fig. 13), sora mijlocie prezintă dentiţie mixtă, cu 13 inclus și persistența lui 53, iar
23 erupt palatinal, cu spațiu redus pentru aliniere și în angrenaj invers cu 33 (anolalie de erupție și poziție) (fig. 14), iar sora cea mai mică prezintă ocluzie inversă lateral dreapta (PM2-M2) și 23 erupt ectopic vestibular (fig.15).

8. Două surori care prezintă spațieri dentare și retracții gingivale determinate de boala parodonta- 

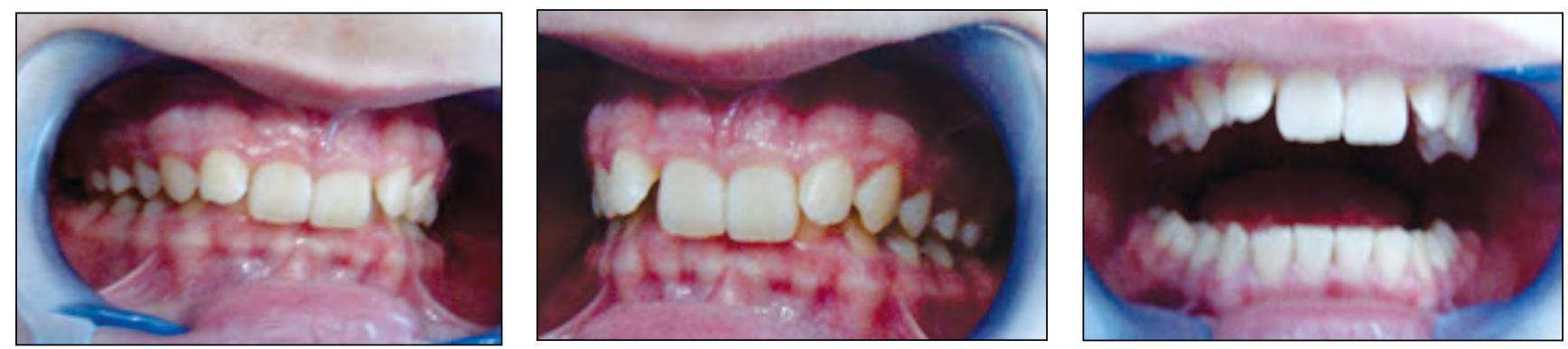

FIGURILE 11A,B,C. S.I., 14 ani - Aspect arcade dentare clasa II/2 Angle de normă laterală dreaptă şi stângă în ocluzie statică şi normă frontală
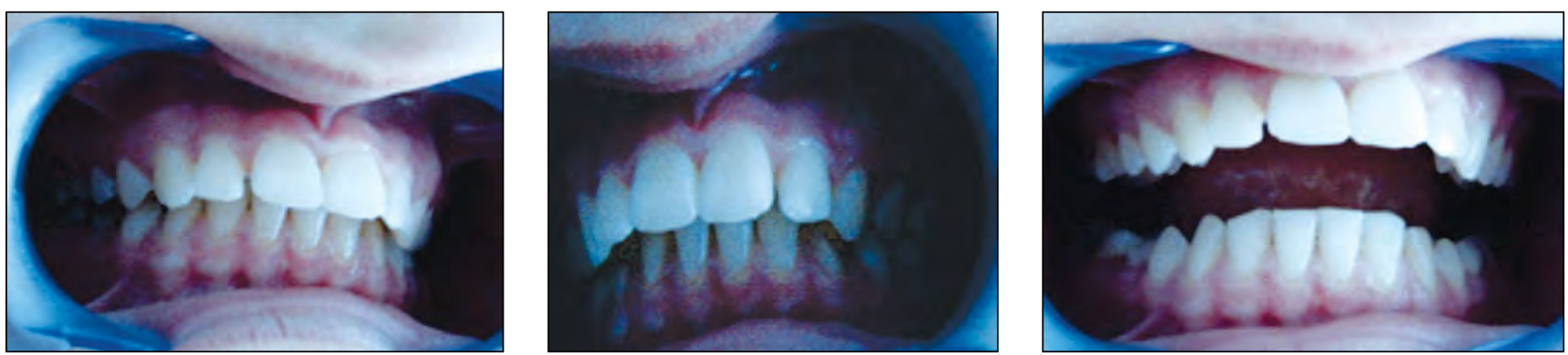

FIGURILE 12A,B,C. S.E., 16 ani - Aspect arcade dentare clasa II/1 Angle de normă laterală dreaptă şi stângă în ocluzie statică şi normă frontală
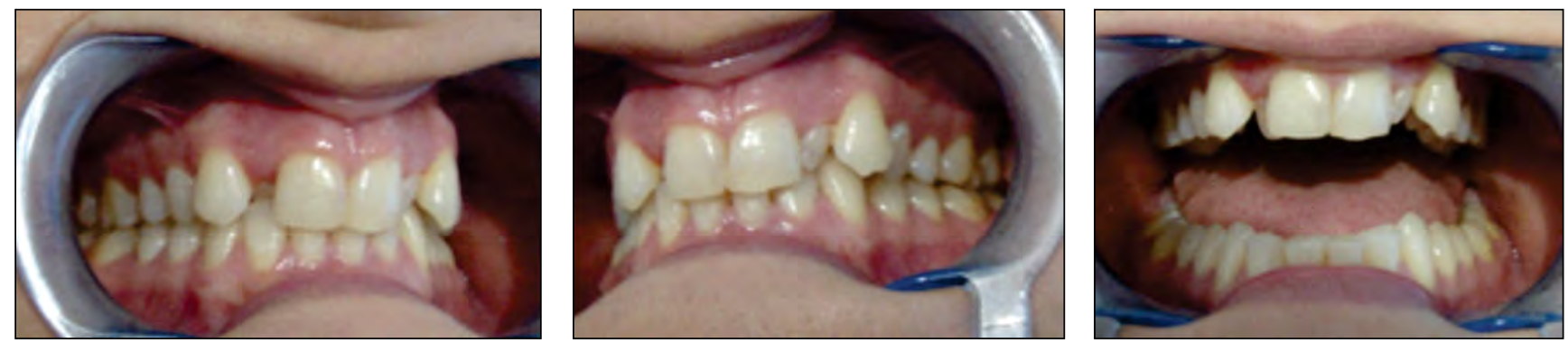

FIGURILE 13A,B,C. Z.H., 21 ani - Aspect arcade dentare (nanism al incisivilor laterali maxilari) de normă laterală dreaptă şi stângă în ocluzie statică şi normă frontală
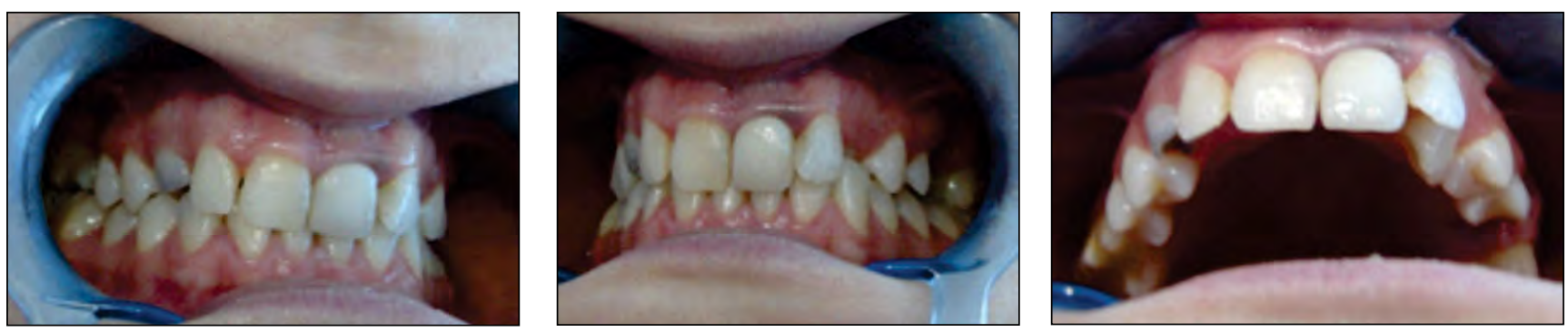

FIGURILE 14A,B,C. Z.A., 18 ani - Aspect arcade dentare (persistenţa 53 şi 23 erupt palatinal) de normă laterală dreaptă şi stângă în ocluzie statică şi normă frontală
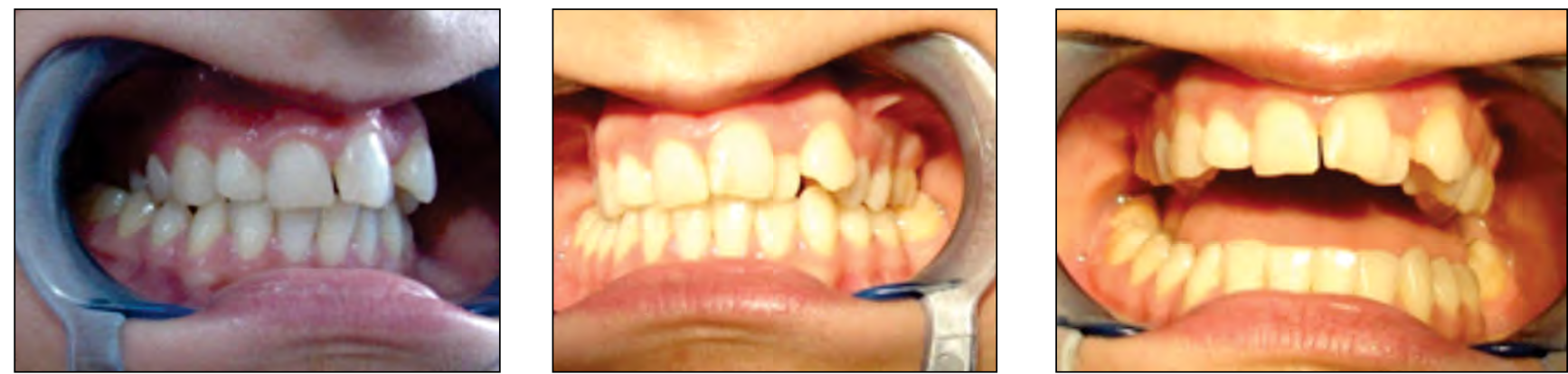

FIGURILE 15A,B,C. Z.C., 16 ani - Aspect arcade dentare (ocluzie inversă lateral dreapta) de normă laterală dreaptă şi stângă în ocluzie statică şi normă frontală 

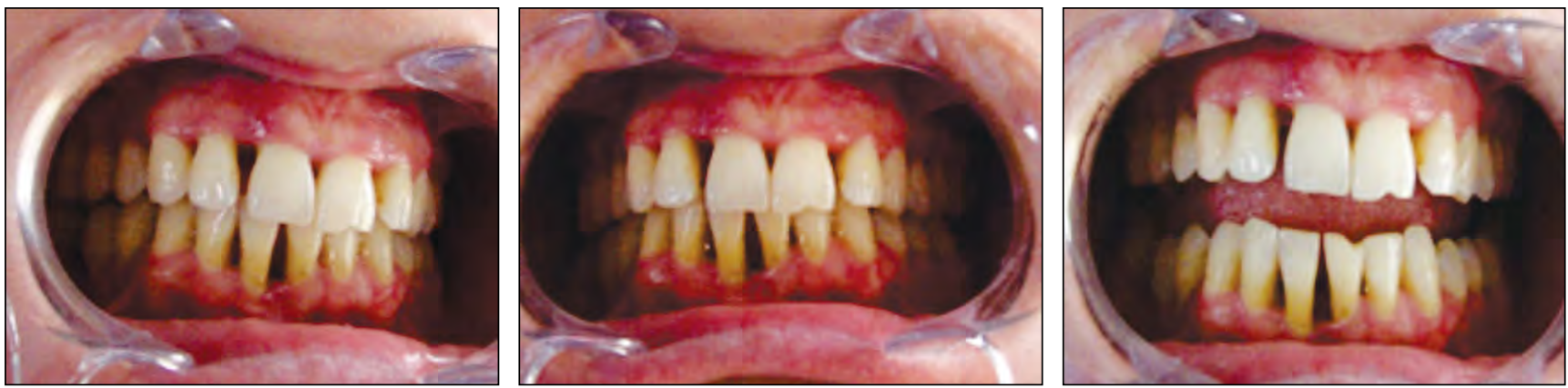

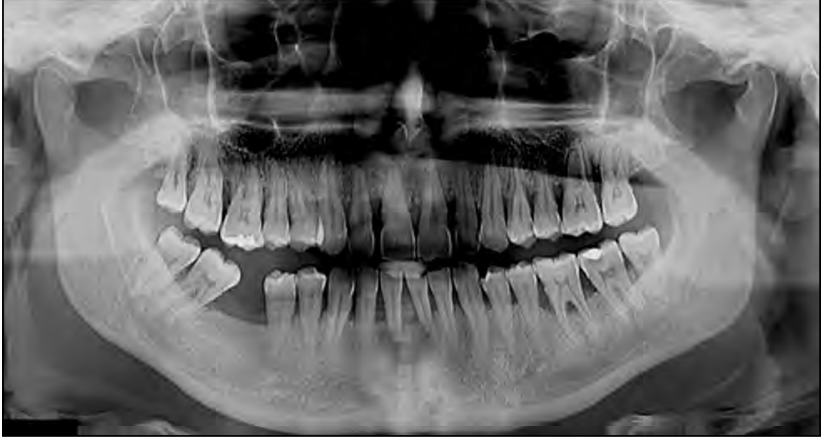

FIGURILE 16A,B,C,D. I.I., 31 ani - Aspectul arcadelor dentare $(A, B, C)$ de normă laterală dreaptă şi stângă în ocluzie statică şi normă frontală şi ortopantomograma (D)
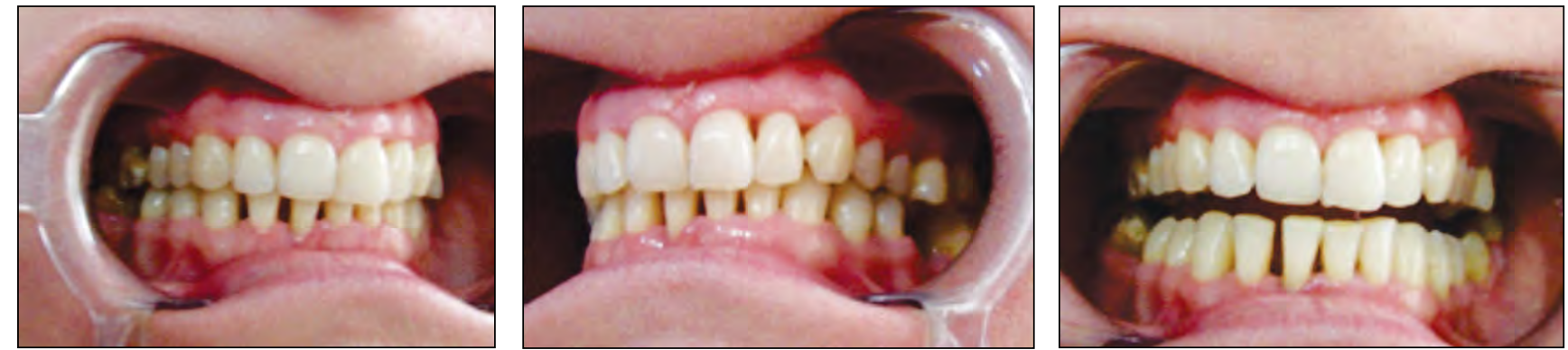

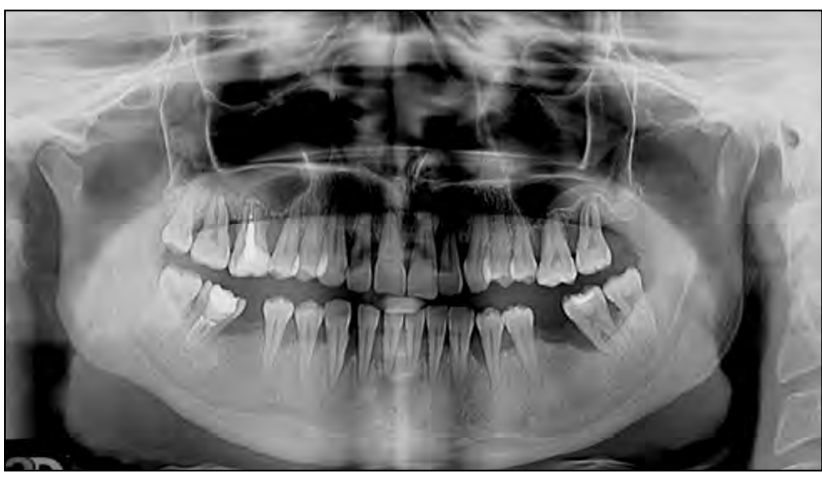

lă (cu atrofie osoasă orizontală generalizată severă), din anamneză fiind posibil transmisă ereditar de la tată (care, la vârsta de 40 de ani, a devenit purtător de proteze totale bimaxilar) (fig. 16 și fig. 17).

\section{DISCUŢII}

Cel mai practic şi semnificativ mod în care genetica va ajuta în practica clinică este identificarea
FIGURILE 17A,B,C,D. M.M., 28 ani - Aspectul arcadelor dentare $(A, B, C)$ de normă laterală dreaptă şi stângă în ocluzie statică şi normă frontală și ortopantomograma (D)

factorilor genetici specifici și a variațiilor factorilor care pot influența trăsăturile cranio-faciale care sunt identificate în cadrul unui individ; nu folosind estimări de ereditate. $\mathrm{Cu}$ toate acestea, din moment ce, practic, nu există niciun aspect al practicii ortodontice care să poată fi preconizat sau explicat cu exactitate printr-o singură mutație a unei gene, așteptarea ca genetica să fie o bilă de cristal care spune totul este nefondată (1). Prin urmare, cel mai probabil va fi o combinație de efecte ale factorilor 
genetici și variații care vor fi esențiale pentru îmbunătăţirea înţelegerii noastre privind modul prin care factorii ereditari acționează asupra numeroaselor fenotipuri complexe oro-dento-faciale şi răspunsurile la tratament $(1,6)$.

Ereditatea este un factor etiologic al anomaliilor dento-maxilare în cazul în care una sau mai multe gene sunt răspunzătoare de un caracter (dominant sau recesiv). Migrația umană și amestecul raselor au dus la creșterea incidenței anomaliilor dentomaxilare, fiind o expresie a multitudinii de combinații genetice, care se supun permanent legii adaptabilității din care poate rezulta un „produs“ armonios sau dizarmonic $(12,15)$. Astfel, tiparul de creștere a bazei craniului, tipul de rotație facială și mandibulară, relațiile intermaxilare și față de baza craniului recunosc un determinism genetic. De asemenea, rata de creștere a maxilarelor, vârsta de erupție a dințiilor, forma dinților și tipul de activare neuro-musculară pot fi influențate ereditar $(18,20)$.

\section{BIBLIOGRAFIE}

1. Hartsfield JK Jr., Jacob GJ, Morford Lorri Ann. Heredity, genetics and orthodontics: How much has this research really helped? Seminars in Orthodontics 2017;23(4):336-347

2. Sridhar Premkumar. Textbook of craniofacial growth. Jaypee Brothers Medical Publisher, 2011

3. Milicescu Viorica, Milicescu Duduca loana. Creșterea și dezvoltarea generală cranio-facială la copii. Ed. Viața Medicală Românească, București, 2001

4. Stanciu D, Dorobăț Valentina. Ortodonție și ortopedie dento-facială Ed. Medicală, Bucuresti, 2014.

5. Enlow DH, Hans MG. Essentials of facial growth. Editura WB Saunders, Philadelphia, 1996.

6. Sperber GH. Craniofacial development. Editura BC Decker Inc, Ontario, 2001.

7. Tamrakar AK, Rathee M. A rare occurrence of non-syndromic hypo-hyperdontia in the mandibular anterior region. J Clin Diagn Res. 2014;8(8):ZL01-ZL02.

8. De Coster PJ, Marks LA, Martens LC, Huysseune A. Dental agenesis: Genetic and clinical perspectives. J Oral Pathol Med. 2009;38(1):1-17.

9. Alvesalo L, Portin P. The inheritance pattern of missing, peg-shaped, and strongly mesio-distally reduced upper lateral incisors. Acta Odontol Scand. 1969;27(6):563-575.

10. Stellzig-Eisenhauer A, Decker E, Meyer-Marcotty P, Rau C, Fiebig BS, Kress W et al. Primary failure of eruption (PFE) - clinical and molecular genetics analysis. Journal of Orofacial Orthopedics/ Fortschritte der Kieferorthopädie. 2010;71:6-16.

11. Frazier-Bowers SA, Long S, Tucker M. Primary failure of eruption and other eruption disorders - Considerations for management by

\section{CONCLUZII}

Pacienții mulțumiți de aspectul estetic dentar și facial obținut după un tratament stomatologic sau ortodontic recomandă de multe ori medicul membrilor familiei, cunoștințelor sau prietenilor. Așa se face că, de multe ori, ortodontul, în decurs de ani, poate ajunge să trateze pacienţi provenind din aceeaşi familie (părinți, frați, surori).

Din experienţa noastră din ultimii ani, ilustrată şi în articolul de faţă, anomaliile dento-maxilare se întâlnesc cu frecvenţă destul de redusă în rândul membrilor aceleiaşi familii, impunându-se necesitatea unor studii aprofundate pe această temă.

Cercetarea etiologiei unei anomalii dento-maxilare ca determinism ereditar are o importanţă deosebită pentru diagnosticul ortodontic, permiţând aplicarea unui tratament adaptat cazului clinic.

Conflict of interest: none declared Financial support: none declared

the orthodontist and oral surgeon. Seminars in Orthodontics. Elsevier; 2016. pp. 34-44.

12. Klein OD, Oberoi S, Huysseune A, Hovorakova M, Peterka M, Peterkova R. Developmental disorders of the dentition: An update. Am J Med Genet C Semin Med Genet. 2013;163(4):318-332.

13. Cruz RM, Krieger H, Ferreira R, Mah J, Hartsfield J, Jr, Oliveira S. Major gene and multifactorial inheritance of mandibular prognathism. Am J Med Genet A. 2008;146A:71-77.

14. Xue F, Wong RW, Rabie AB. Genes, genetics, and class III malocclusion. Orthod Craniofac Res. 2010;13:69-74.

15. Ting TY, Wong RWK, Rabie ABM. Analysis of genetic polymorphisms in skeletal Class I crowding. Am J Orthod Dentofacial Orthop. 2011;140:e9-e15.

16. Sciote JJ, Horton MJ, Rowlerson AM, Ferri J, Close JM, Raoul G. Human masseter muscle fiber type properties, skeletal malocclusions, and muscle growth factor expression. J Oral Maxillofac Surg. 2012;70:440-448.

17. Romanec C, Păcurar M, Decusară M, Scutaru MM, Hînganu D, Hînganu MV, Ciupilan C. Labio-palatine cleft, morphological substrate. Rev Chim. 2018, 69(4):1002-1005.

18. King RA, Rotter JI, Motulsky AG. Approach to genetic basis of common diseases. Oxford: Oxford University Press; 2002.

19. Ogodescu A. Tratamentul ortodontic la adult. Ed. Eubeea, Timișoara, 2008.

20. Yamaguchi T, Maki K, Shibasaki Y. Growth hormone receptor gene variant and mandibular height in the normal Japanese population. Am J Orthod Dentofacial Orthop. 2001;119:650-653. 